\title{
Vertical Disintegration and the Disorganisation of German Industrial Relations
}

\author{
Virginia Doellgast \\ Ian Greer \\ Published in the British Journal of Industrial Relations, Vol. 45, No. 1, pp. 55-76, March \\ 2007
}

\begin{abstract}
Summary
Drawing on case studies from the telecommunications and auto industries, we argue that the vertical disintegration of major German employers is contributing to the disorganisation of Germany's dual system of in-plant and sectoral negotiations. ${ }^{1}$

Subcontractors, subsidiaries, and temporary agencies often have no collective bargaining institutions, weaker firm-level agreements, or are covered by different sectoral agreements. As core employers move jobs to these firms, they introduce new organisational boundaries across the production chain and disrupt traditional bargaining structures. Worker representatives are developing new campaign approaches and using residual power at large firms to establish representation in new firms and sectors, but these have not been successful at re-building coordinated bargaining.
\end{abstract}

\footnotetext{
${ }^{1}$ Field research for this paper was supported by the Fulbright Commission, the German Academic Exchange Service, Cornell University School of Industrial and Labor Relations, Cornell University's Einaudi Center and the Max Planck Institute for the Study of Societies. Thanks to Marco Hauptmeier, Ursula Holtgrewe, Gregory Jackson, Christine Trampusch, and Lowell Turner for valuable comments. An earlier version of this paper was presented at the Collective Bargaining Workshop at Cornell-ILR, the MITCornell Graduate Student Workshop, and the 2005 Society for the Advancement of Socio-economics conference.
} 
The future of industrial relations in "social Europe" is increasingly uncertain, as European trade unions seek new strategies to slow declining membership and political influence. Corporate restructuring has played a central role in these changes. Collective bargaining in traditional union strongholds has shifted from the national or industry level to the establishment level (Katz and Darbishire 2000). Meanwhile, growing numbers of firms are leaving employers' associations or setting up greenfield operations outside of collective agreements.

There is broad agreement that European industrial relations institutions are changing. However, there continues to be disagreement on the long term prospects of a European social model characterized by strong, inclusive unions and broad industrial citizenship rights. Germany has been at the centre of these debates, due to its tradition of strong, coordinated collective bargaining and a remarkably robust trade union movement (Turner 1991; Thelen 1991; Hall and Soskice 2001); and has more recently become a key test case for analyzing the stability or erosion of these institutions (Yamamura and Streeck 2003; Paterson and Green 2005).

A key question in this literature is how firm strategies to restructure production affect bargaining structures and trade union bargaining power. In this paper, we analyze the effects of one common but under-studied form of restructuring - vertical disintegration - on German industrial relations, drawing on case studies from the telecommunications and auto industries. Vertical disintegration is typically defined as the creation of new intermediate markets in a previously integrated production process (Jacobides 2005: 465). This can include subcontracting production to a separate firm, the 
creation of independent subsidiaries, and use of temporary agencies for staffing. The common change we describe is one that moves production or services from vertically integrated hierarchies to networks characterized by more market-based relations between two or more organizations, typically dominated by a single powerful customer.

We argue that vertical disintegration creates substantial challenges for trade unions that make it increasingly difficult to maintain or rebuild the institutions that are the core of Germany's "dual system" of collective bargaining. Vertical disintegration differs from other forms of organizational restructuring, such as decentralization of decision-making and mergers and acquisitions, because it sets up more competitive markets for investment within and across firms and introduces new sectoral boundaries across the production chain of large "core" firms. There are two main ways that this undermines coordinated bargaining. First, vertical disintegration allows managers to move jobs from a well-organized core to a more poorly organized periphery of firms that have no collective agreements or that are covered by firm-level agreements. Alternatively, it results in a shift of work to new sectoral agreements, typically negotiated by different unions. Under both scenarios, employers are able to segment their workforce in new ways, increasing variation in wages and working conditions and undermining coordinated bargaining.

In the following section, we review the literature on continuity and change in the German model of industrial relations. We show that most research to date has treated bargaining decentralisation within core firms and the growth of a peripheral "disorganised" sector as separate phenomena, without analysing the relationship between them. Second, we discuss recent developments in Germany that have contributed to the 
growing popularity of outsourcing, and present national data from Germany that demonstrate increased vertical disintegration across sectors. In the third section, we present findings from case studies conducted between 2003 and 2004 in the telecommunications and auto industries. We conclude with a discussion of the implications of our findings for comparative industrial relations theory and research.

\section{Change in German Industrial Relations}

The German system of industrial relations remained surprisingly stable throughout the 1970s and 1980s, at a time when union density and influence were declining in most other industrialized countries. This stability was attributed to the unique characteristics of the "dual system" of interest representation, which combined coordinated sector-level wage bargaining with establishment and firm-level codetermination. Despite the legally mandated separation between works councils and unions, in-plant and sectoral labour representatives worked closely together. Firms relied on employer associations for a wide range of services and paid workers according to sectoral agreements. The labour movement used leverage from this bottom-up/top-down coordination to win gains in well-organized industries and regions, such as the harbours or auto plants, and spread them to poorly organized places, like hospitals or electronics plants (Turner 1991; Thelen 1991).

Even in their more contentious moments, German unions acted within this system - anchored both in law and customary practice - as social partners responsible both for industrial adjustment and for worker well-being. The widespread application of sectoral 
collective agreements (between 70 percent and 80 percent of workers in metalworking industries) and stable union density (around 40 percent overall between 1970 and 1990) gave organized labour a great deal of influence over pay and working conditions. The German model delivered both equity and efficiency by putting socially desirable constraints on business that stimulated investment in skills, promoted social peace, and enhanced corporate performance (Streeck 1992). These outcomes in turn proved to be a stable source of competitive advantage for firms in export-oriented manufacturing industries (Hall and Soskice 2001). For many different reasons, these writers saw in Germany a society stabilized by strong industrial relations institutions.

Over the 1990s, evidence began to accumulate that Germany's industrial relations institutions were weakening. Surveys showed that concessionary plant-level bargaining in both eastern and western Germany, some of it illegal, was becoming common practice (Massa-Wirth and Seifert 2004). Sociologists documented cases where intensified global competition and growing unemployment were allowing a rollback of in-plant worker participation to their legal minima, even in large firms with a strong union presence (Springer 1999). The news media reported on highly visible union defeats in union strongholds, such as the lost metal industry strike of 2003 and concessionary agreements on pay and working time at DaimlerChrysler, Siemens, and VW.

Meanwhile, the membership density of unions and employers associations and the coverage of collective bargaining steadily deteriorated (Hassel 1999). By 2003, union membership had fallen to around 8 million from the post-unification peak in 1991 of 14 million (Schroeder and Wessels 2003). Local employer associations, in hopes of retaining members, established non-union affiliates to help companies cope with labour law and 
human resource issues without binding them to a sectoral agreement (Schroeder and Silvia 2003). Alternative private service providers began offering works councils training and advisory services, often replacing unions in this role (Rossmann 2001).

There is a growing literature on the changes under way in Germany's coordinated model of industrial relations. Institutional scholars who long argued that the German model was a competitive alternative to liberal markets have begun to take seriously the effects of neoliberal policy, changing corporate organization, and the growth of shareholder value on industrial relations (Streeck and Thelen 2004; Katz and Darbishire 2000; Paterson and Green 2005). At the same time, there continue to be different interpretations of the mechanisms through which change occurs and how these changes will in turn affect the stability of dual system bargaining institutions in Germany.

One argument holds that employer interests in industrial peace lead them to support stability in bargaining arrangements, at least in core sectors and among large employers. Thelen and her colleagues (Thelen and Kume 1999; Thelen and Van Wijnbergen 2003) have argued that German employers are not interested in breaking the dual system apart. They point to positive strike settlements on the unions' terms in the metalworking industry and continued commitment of employers' associations to bargaining as evidence that sectoral agreements are still relatively stable and encompassing institutions.

A second, and complementary, argument holds that Germany's strong codetermination institutions persist because of their ability to adapt to changing market conditions. Streeck (2001) has argued that co-determination continues to provide a great 
deal of flexibility. Managers can outsource, sell their subsidiaries, downsize, merge and engage in a wide range of other activities without sparking conflict with worker representatives (Streeck 2001). Research on large German firms has found that unions and works councils have done little to oppose the introduction of shareholder value as the dominant goal of corporate governance (Höpner 2003) and much to allow flexibility through firm-level pacts (Rehder 2003). Thus, although formal institutions have remained stable, the German bargaining system has changed through new innovations by labour and management representatives (Hassel and Rehder 2001; Jackson 2005).

Other writers have come to similar conclusions. Frege (2003) presents survey evidence that works councils in several sectors have maintained cooperative attitudes and sustained some balance of power with management despite deteriorating bargaining conditions. Behrens and Jacoby (2004) argue that unions and employers associations create "firewalls" that prevent new innovations in organizing strategies or work organization from undermining the overall "logic" of German industrial relations. These scholars agree that German institutions are changing, but in a gradual and path-dependent manner, which Streeck and Thelen (2004: 4) term "transformation without disruption."

\section{Vertical disintegration and the disorganization of sectoral bargaining}

We argue here that vertical disintegration contributes to more disruptive changes in Germany's industrial relations institutions. Political economy scholars have long debated how changes in the organisation of production would affect workers and their representatives. One group of scholars argued that workers would gain bargaining power, 
as new network-based production models required increased investments in skills and union participation in implementing new models of work design (Piore and Sabel 1984). Others warned that the growth of outsourcing would allow powerful buyers to push risks of fluctuating demand onto the workforce of supplier firms, which in turn would aggravate economic and social dualism (Harrison 1994). Researchers who studied dual labour markets in the US and Japanese Keiretsu in the 1970s and 1980s similarly argued that subcontractors and small firms constituted a secondary sector that supported the high wages and job security in core workplaces (Dore 1973; Doeringer and Piore 1971).

The more encompassing industrial relations institutions in continental European countries were thought to make it more difficult to set up core-periphery labour markets. Esping-Andersen (1990) observed that Germany experienced a very different postindustrial employment trajectory in the late 1980s than the US, with sluggish service growth compared to the US's explosion in business-related services and junk jobs. Centralized collective bargaining backed up by informal links across works councils within and across sectors effectively took wages out of competition. Researchers studying the introduction of lean production in the German auto industry in the late 1980s and early 1990s found that unions and works councils effectively incorporated the major subcontractors into industry agreements and maintained coordinated bargaining across these firms (Turner 1991).

Several changes since the early to mid-1990s have made outsourcing both more attractive to German firms and more disruptive to sectoral bargaining. First, union membership and collective bargaining coverage have declined, and therefore German trade unions find it more difficult to maintain pressure on employers outside core 
workplaces. The flight of small firms from employers' associations have increased wage inequalities between the sectors opened up a gap in regulation that previously existed at a much smaller scale (Thelen and Van Wijnbergen 2003). Second, competitive pressures have intensified across sectors of the German economy. While export-oriented manufacturers faced intensified price competition in the early 1990s, public ownership and strong job security agreements in many service industries meant that extensive outsourcing remained costly and politically difficult. As telecommunications, banking, airlines, and a range of other industries were deregulated in the 1990s, companies faced growing price competition and began to look for lower cost alternatives, often in partnership with worker representatives, for handling certain "non-core" jobs.

This contributed to a third recent trend: the growth of new industry segments providing outsourced services - such as IT, call centre, cleaning, and temporary agency services. The boom in outsourcing of support services in Europe lagged about five to ten years behind the US (Doellgast 2006; Arzbacher, Holtgrewe, and Kerst 2002). As the market and profile of these new niche sectors expanded, more firms started taking seriously the option of outsourcing or spinning off work, leading to a boom in business process outsourcing. A 2004 report from the consultant group TPI found that Europe accounted for close to half of the value of major outsourcing contracts, doubling in value over 2002; IT outsourcing led the trend, and business process outsourcing was making rapid gains (TPI 2005). Deutsche Bank's decision in 2003 to shift a large share of its European IT operations to IBM was treated in the press as a bellwether case, signalling the eroding hold of unions on the investment strategies of their companies (Blau 2003). According to the Fraunhofer Institute's survey of 1630 manufacturing firms, 41 percent 
of companies surveyed had outsourced production between 1999 to 2001, while only 12 percent had "insourced" production, or brought it back into the firm (Kinkel and Lay 2003).

Temporary agencies have also become a more established sector over the past decade, making it easier for firms to outsource staffing to a third party. Regulations limiting the length and renewal of temporary postings have been gradually relaxed since the mid-1990s. A 2002 law lifted most restrictions on temporary work but required equal pay and equal treatment of temporary workers, with a loophole in the case of a collective agreement. Two major employers associations formed to negotiate on behalf of temporary help agencies, and in 2002 agreed with the Confederation of German Trade Unions (DGB) on a skill-based pay scale with 13.5 percent lower rates in the east (Dribbusch 2003). This agreement gives temporary agencies a guideline for pay that deviates from collectively agreed minimums in the firms that contract with them.

Although benchmarking, spreading risk, obtaining technology, cutting overhead, and dealing with demand swings are important reasons for outsourcing and using temporary agency workers, evidence suggests these strategies are also used to avoid high wages and additional costs associated with collective agreements. Two separate surveys have found that German managers cite cost reductions as the top reason for outsourcing (Hendrix, Abendroth, and Wachtler 2003; Kinkel and Lay 2003). Hendrix et al. (2003: $44,118,140$ ) find (in an exclusively West German sample) that firms that outsource work are usually successful in winning savings, and that contractors are less likely than other firms to be covered by collective bargaining and more likely use contingent workers. 


\section{Vertical disintegration in two sectors}

Available evidence shows that German firms are continuing to shift work to subcontractors and subsidiaries, and in some cases have used these strategies to undermine sectoral bargaining. There has been less systematic comparative research on how outsourcing affects industrial relations in different sectors, and how unions are responding. In this section, we present findings from two sectoral case studies: a privatized infrastructure industry (ver.di and IG Metall-represented call centres in telecommunications) and an export-oriented private industry (IG Metall-represented auto plants). Our findings are based on over 150 interviews between 2003 and 2004 with managers, employees, works councillors, trade unionists and policy-makers. We chose two sectors that have been treated as key cases of strong social partnership in past research on German industrial relations (e.g. Turner 1991; Katz and Darbishire 2000; Thelen 1991), and that are diverse along several dimensions, including the union involved, level of exposure to international competition, and work characteristics.

Within each sector, we chose the largest employers, including the former telecommunications monopolist and three of its major competitors in the fixed wireline and wireless markets, and three of the five largest automakers. Taken together, these case study firms represent over 450,000 employees in sectors employing close to one million employees. In addition, we conducted interviews and site visits in both West and East Germany, to avoid possible biases in our analysis due to differences in union strength and coverage across the two regions. 


\section{Telecommunications ${ }^{2}$}

The telecommunications industry in Germany changed rapidly after the Deutsche Bundespost was privatized and deregulated in the mid to late 1990s, moving from a publicly-owned monopoly with one strong union (the Deutsche Postgewerkschaft (DPG)) to a highly competitive information services sector with multiple unions. Because the DPG negotiated the wages and working conditions for all of Deutsche Telekom's (DT) employees in a single-firm agreement, no industry association existed to incorporate new market entrants. These firms have been reluctant to cooperate with the former monopolist or jeopardize their cost advantage through new collective agreements. In addition, the DPG negotiated separate agreements with DT's core wireline business (T-Com) and its newer subsidiaries, such as the wireless subsidiary T-Mobile, leading to growing variation in pay and working conditions within the company (Sako and Jackson 2006). Unsuccessful negotiations with the internet subsidiary T-Online continued through the DPG's merger with the conglomerate service union ver.di, but were cut short when TOnline was brought back into DT's core business in 2005.

Today DT's major competitor in the wireline and internet services segments is Arcor, which was formed through the merger of o.tel.o, covered by an agreement with the chemical union IG Chemie and public sector union ötv, and Mannesmann Arcor AG \& Co., a joint venture of Mannesmann (under IG Metall's jurisdiction) and the Deutsche Bahn (represented by Transnet). The British-owned firm Vodafone is T-Mobile's largest

\footnotetext{
${ }^{2}$ This section summarizes research presented elsewhere (Doellgast 2006: chapters 2 and 3).
} 
competitor in the wireless segment, and negotiated a single-firm agreement with IG Metall after its hostile take-over of Mannesmann in 2000. Many of the smaller regional service providers and foreign-owned MNCs who more recently entered the German market have avoided unions altogether. E-Plus, a Dutch-owned company that is currently the third largest wireless network provider in Germany, has a central works council but still no union agreement. Today trade unions vying for influence in the telecommunications industry face substantial challenges from fragmented collective agreements, union rivalry, and a growing non-union sector. ${ }^{3}$

Changing employer strategies. Deutsche Telekom, Arcor, Vodafone, and E-Plus have all responded to growing cost pressures in the telecommunications market by subcontracting lower skilled construction, installation and service work. Call centre services have been a major target, due to technological advances in the mid-1990s that lowered the costs of networking remote sites and contributed to a boom in call centre vendors. Several firms turned over all or most of their call centre operations to these vendors, which then took over the management of the existing workforce. In 2002, TOnline sold three locations to different vendors and the mobile phone company E-plus sold all three of its call centre locations to the Dutch vendor SNT, affecting close to 2,000 workers. T-Online kept only 10 percent of call volume in-house to benchmark vendor performance.

\footnotetext{
${ }^{3}$ Although there are no recent estimates of union density in telecommunications, works councilors and unionists interviewed estimated between $20-30$ percent membership density and 70 percent coverage by union-negotiated collective agreements - not including subcontractors. However, these are all firm-level agreements by different unions, and many do not include pay.
} 
The other case study firms have all outsourced some portion of their call centre work to increase flexibility in responding to daily and seasonal peaks in call volume or to cut labour costs for less complex jobs, like outbound sales or directory assistance. T-Com sent 2,800 of its 3,500 directory assistance jobs to a vendor, reshuffling those employees to its customer service centres and expanding subsidiaries; while T-Mobile gradually increased its use of vendors for outbound campaigns, late nights, and weekends. Vodafone began outsourcing all call peaks and new calls (around four percent a year) as growth in the wireless market fell off and competition increased in the early 2000s. This did not lead to job cuts, but meant no new expansion of the in-house workforce. After Arcor merged with o.tel.o, the new company set up a separate subsidiary for its call centre operations. The new company immediately outsourced all directory assistance jobs, and continued to contract with o.tel.o's vendors for peaks, late nights, weekends, and outbound campaigns. Works councillors estimated around 200 jobs were outsourced, or 30 percent of call volume.

Union and works council responses. Labour representatives had varying influence over outsourcing decisions at the six firms discussed above, due to differences in the strength and coordination of works councils and trade unions. Management at TOnline and E-Plus faced only minimal resistance due to divided works councils and a weak union presence. Works councillors at the locations that had been sold off to vendors spoke of feeling "abandoned" by the central works councils, who appeared to be more concerned with maintaining the competitiveness of their companies and the higher skilled jobs of the larger technical and professional workforce. After two years, these agents 
were no longer protected under their former employment contracts, and were forced to accept cuts in pay, breaks, and vacation time as their new employers tried to stay afloat in the extremely price-competitive vendor industry.

At Vodafone, Arcor, T-Mobile, and T-Com, outsourcing initially served as an escape valve that allowed unions and works councils to avoid making politically difficult compromises as management stepped up demands for wage concessions, "unsocial" working hours (late nights and weekends), and individual-based performance monitoring. Although co-determination rights do not extend to these kinds of restructuring decisions, management consulted with labour representatives in firms with stronger, more coordinated works councils to avoid potential conflict. The DPG and T-Com's works councils decided in the late 1990s to allow management to outsource simple directory assistance work rather than accept a lower pay scale. Similarly, at Vodafone, works councils allowed management to outsource seasonal peaks in call volume in exchange for strong job security protections. In both cases, outsourcing was presented as an alternative to other concessions that would directly affect the pay and working conditions of the core workforce.

These strategies temporarily shifted problems of low pay, speedups, and job insecurity onto the vendors' employees. However, in the long-term they created new pressures for concessions. Labour costs at vendors are up to 40 percent less than those at telecommunications call centres, monitoring rules are more relaxed, and employees are more likely to be employed under short-term contracts. As firms began to benchmark the performance of vendors with their internal workforce, they stepped up demands for new collective agreements that would bring costs in line with vendors. 
Unions responded with organizing and campaign strategies that attempted to establish representation in new workplaces. When the industry was deregulated in 1998, the DPG formed the project Telekommunikation, Informationstechnologie, Medien (T.I.M) to organize new firms and industry sectors. These efforts succeeded in getting works councils elected at most large call centre vendors, and provided them with advising and legal services that resulted in improved work conditions. Many employers were not providing the legally mandated Bildschirmspause, an hourly break from the computer screen. By mobilizing around this health and safety issue, with the DPG's support, works councillors were able to increase break times for employees in several workplaces, reducing stress and improving the overall work climate. The union also organized to win equal pay for part-time workers under the terms of a widely disregarded EU directive, which helped the DPG increase union membership in some new firms, including E-plus. Building on these efforts, ver.di negotiated a collective agreement with the largest third party call centre, Walter Telemedien, which was handling Telekom's directory assistance.

Despite these successes, however, most call centre vendors continue to have weak or no collective agreements and union representation is fragmented across both the telecommunications and vendor industries. US-owned vendors have been particularly aggressive in closing call centres with activist works councils and moving work to locations where they are more "employer friendly." Regional efforts to build cooperation across unions, works councils, and local governments have fizzled out due to lack of interest and resources.

In this environment, labour representatives are turning to strategies that rely on residual power and influence, leveraging bargaining strength in core firms to extend 
representation, bring work back in-house, and avoid further loss of work. In return for negotiated assurances against establishment closures, or Standortsicherungsvereinbarungen, unions and works councils are willing to grant concessions that reduce the cost and flexibility differences between in-house and third-party workers. After TMobile outsourced and closed some locations in the late 1990s, the DPG negotiated an agreement that limited layoffs while agreeing to a more "flexible" work time model and a lower pay raise. In T-Com, ver.di has used strong job security protections and wage concessions to bring outsourced call centre work back into the corporation. In 2004, ver.di and DT worked out an agreement to create a new subsidiary called Vivento Customer Services (VCS) that now handles simple call centre services, employing workers who had been made redundant by earlier rounds of layoffs at 90.5 percent of their regular pay. Unionists viewed this as a coup that would allow management to "insource" work that had earlier been subcontracted out across the subsidiaries and to compete head to head with non-union vendors. However, management recently announced further job cuts across DT, including plans to close 45 call centres and increase outsourcing.

In sum, worker representatives have experimented with new strategies to influence outsourcing decisions, organize new firms, and establish coordinated regulation across telecommunications and call centre vendors. However, these efforts are still piecemeal. Unions and works councils have had some success in halting or reversing outsourcing in firms where they have an institutional mooring, but at the expense of concessions. Outside of Deutsche Telekom, in-firm agreements occur in consultation with weaker and more easily intimidated works councils with low union density. Neither 
new organizing approaches nor strategies to leverage residual power fully address growing worker-to-worker competition, and may even exacerbate it.

\section{Automobile Manufacturing}

The German auto industry has long served as the exemplary case of high-quality production, cooperative industrial relations and worker participation (Turner 1991; Katz and Darbishire 2000; Streeck 1992). Until reunification and the opening of Germany's eastern borders, worker participation rights at Volkswagen, Daimler-Benz, Opel, BMW, and Ford were the envy of the world. The growth of low-cost competition and rising unemployment have allowed employers to gradually roll these rights back (Springer 1999). As domestic markets became saturated and both mass and luxury markets grew increasingly price-competitive in the 1990s, auto manufacturers pursued new strategies to cut costs and increase productivity. One such strategy was to create internal markets that forced plants to bid on new investment. German firms have, as a whole, done well in this competition: the number of cars produced has increased from 4 million to 5.2 million since the 1993-94 industry crisis, bringing the number of employees up from 657,000 to 773,000 . While this growth has come at the cost of concession bargaining, the overall employment and production figures in Germany are quite robust.

IG Metall remains the major union in the auto industry, and, unlike telecommunications, all large employers are members of the industry association Gesamtmetall and thus signatories to the sectoral agreement for the metal and electrical industry. However, the coverage of this agreement has been shrinking as smaller firms 
leave Gesamtmetall. In 2001, 62 percent of employees in West Germany and 28 percent in East Germany were working in member companies, a decline since 1991 from 68 and 54 percent respectively (Schroeder and Wessels 2003: 671).

Changing employer strategies. We focus here on three of the largest Original Equipment Manufacturers (OEMs) in Germany: Volkswagen, Daimler-Benz, and Ford. All three have differentiated pay and working conditions through three strategies: setting up new subsidiaries, outsourcing manufacturing and services activities and using temporary agencies. ${ }^{4}$ Subsidiary strategies have taken several forms. VW established a new subsidiary in East Germany, VW-Sachsen, which performed a highly lean form of auto assembly and engine production that made heavy use of suppliers and agency temps. Regular workers were paid at East German wages, which were lower than the "house agreement" in the West, and temporary workers and local suppliers allowed further cuts in labour costs. A second strategy is to spin off parts production to a separate company. Daimler recently opened an engine plant and VW set up a fuel injection plant in East Germany, both of which were greenfield locations jointly owned by another company. Ford pursued a similar strategy, but converted existing parts plants in West Germany and West Berlin into the new company Visteon. Lastly, companies set up subsidiaries to compete with suppliers, often with little production in Germany and not under the

\footnotetext{
${ }^{4}$ Since the concessionary agreements of 2004-5, most of the OEMs also differentiate wages according to seniority. That is, workers hired after a certain point come in under in-plant agreements that have eliminated or reduced payments over the level of the sectoral agreement. Unlike outsourcing, this falls in the category of firm-level pacts, which are coordinated by the standard collective bargaining channels.
} 
sectoral agreement. VW has done this with wire harnessing (VW Borgnitzer) and logistics (Schnellecke).

Outsourcing has also taken different forms. First, all three firms outsource parts production to third-party suppliers. Some suppliers have stable employment and conditions comparable to the OEMs, such as the large "lead factories" of mega-suppliers like Bosch that combine development and production functions. Much of the new work, however, occurs adjacent to assembly plants in small, dedicated plants, linked to, and dependent on, changing production volumes. Auto assembly plants like Ford-Cologne and Mercedes-Rastatt put these producers in industrial parks (Juergens 2001); most other plants have such dedicated plants linked to them on a just-in-time basis. While nearly all auto assembly plants are covered by sectoral agreements or better, suppliers are covered by a patchwork of sectoral, firm-level and plant-level agreements.

A second strategy is to outsource indirect work within the factories, usually to MNCs like Sodexho, Hoermann or TNT that specialize in such functions as forklift driving, tooling, maintenance, cafeteria and cleaning services. The three case study firms have different strategies in this area. Ford does not outsource any support services in its assembly plants, but its subsidiary Visteon outsources all services. DaimlerChrysler and VW differ by plant: for example, VW-Sachsen has outsourced all support services, representing around a fifth of on-site jobs, while other VW plants range from no to partial outsourcing.

Third, OEMs increasingly contract work out to temporary agencies, including firms like Manpower or VW's Autovision project. These agencies supply both skilled 
and semi-skilled workers, who work alongside the permanent workforce. VW's Chemnitz engine plant and Visteon's Berlin plant, with core workforces of 5-600 workers, each have more than 100 agency temps. Assembly plants employ much smaller proportions of agency temps; VW's Zwickau assembly plant employs as many as 450 agency temps out of a workforce of 6,000. At VW's Dresden assembly plant and the DaimlerChryslerMitsubishi joint venture near Erfurt, only half of the workers on-site work for the "core" firms; the rest work for temporary agencies or service providers.

Because of these strategies, the percent of value-added declined at all of the major automakers during the 1990s. According to IG Metall's analysis of corporate financial statements, every automaker except for Porsche reduced its percent of value added between 1989 to 1998, and the overall "production depth" declined from 41 percent to 35 percent (Caprile 2000). Managers and union representatives report that over the past decade, corporate spinoffs, assembly plant re-tooling and new joint ventures have shifted additional work out of the assembly sector.

Union and works council responses. Worker representatives in the auto industry have accepted that these moves were necessary to keep the OEMs competitive and to keep jobs in Germany. Hard-pressed works councillors (with the support of IG Metall) have accepted greater competition and internal segmentation, and - with a few exceptions - have not sought to bring work back in-house as in telecommunications. At the same time, the increased variation in wages and working conditions across subsidiaries, suppliers, service providers, and temp agency workers have increased pressure for 
concessions and made the in-house workforce more wary of new strategies to shift production outside of the "core."

IG Metall and works councillors in the OEMs face growing pressure to adopt new strategies aimed at "re-regulating" new work, and have responded in several ways. First, they have adopted campaign approaches to organize new subsidiaries and subcontractors and incorporate them into collective agreements. However, because workers lack formal co-determination rights on corporate restructuring decisions, unions typically are forced to wait until the new plant is open to begin a campaign and then must work from the ground up with weak institutional supports. Local IG Metall offices and OEM works councils play important roles in establishing new works councils and bargaining with management in spun-off plants. At Visteon, the head of the Ford works council successfully established transnational worker representation in the new company. When Ford's supplier park opened in Cologne, representatives from the local IG Metall recruited union activists to take new jobs and set up works councils and in some firms won house agreements. At Mercedes' supplier park in Rastatt, the core works council not only helped establish new works councils and apply collective agreements, but also kept them informed about swings in production. In Stuttgart - the core of DaimlerChrysler's production network - the local IG Metall has set up periodic meetings of auto suppliers to keep them up to date on the situation at the OEM. The level of coordination depends on communication between different works councils across the supplier chain, and thus varies substantially from case to case based on local personalities and interest.

Works councillors and union representatives have also used residual power and influence from their existing relationships with the OEMs to cope with vertical 
disintegration. These strategies were adopted more or less simultaneous with new organizing efforts, as international competition created early pressures to reduce labour costs. In agreements to allow outsourcing (usually part of a large package of wage and working time concessions), works councils often win job security guarantees, investment guarantees, early retirement and some assistance finding new work. While the VW and Visteon works councils have largely accepted the outsourcing of in-plant work, the DaimlerChrysler works council has negotiated alternative forms of cost-cutting. Works councillors made especially deep concessions for workers in support services, in lieu of outsourcing, and cooperated with a program that allowed management to shift young workers from plant to plant in lieu of the use of agency temps.

One major use of existing relations with OEMs has been through international work, spreading standards - or concessions - across the firm's production chain. International solidarity work at DaimlerChrysler, for example, has included framework agreements with strong enforcement mechanisms to rectify abuses of core labour rights within the companies' global supplier chains. Unions and works councils have negotiated Europe-wide collective agreements to protect workers in spun-off supplier companies. At Visteon, IG Metall signed an agreement in 2003 covering plants in Germany, France and the UK, which detailed a series of painful measures that increased outsourcing and the use of temporary employees while reducing employment substantially. In return, companies often make detailed changes in each plant's product palette and provide investment guarantees.

Despite these efforts, subsidiary and outsourcing strategies have moved a growing number of workers to new sectoral agreements with lower wages and in some cases 
barely existing employers' associations. ${ }^{5}$ In-plant forklift operators increasingly abide by ver.di's "logistics" agreement, janitors according to IG BAU's "building cleaning" agreement, and agency temps according to the DGB's agreement for agency temps. With the agreement of IG Metall, VW Sachsen quit the Sachsen employers association over a disagreement over bargaining policy. Although the employer joined the sister association in Brandenburg, this move deprived IG Metall of its strongest strike target in the state.

The shift of jobs from the metal sector to firms with weaker collective bargaining institutions creates major challenges for local IG Metall officials and works councillors. The emergence of supplier parks creates a conflict of interest between OEM works councillors, who often want those jobs for their own constituents, and works councillors in the suppliers, with an interest in job retention. At Visteon, the firm's inability to win work outside of Ford is forcing layoffs and concessions, and the possibility of the OEM subsidizing its former supplier is declining with every year. When OEMs shift suppliers, there is often little the works council or IG Metall can do to prevent find new jobs for the employees of the losing contractor. The situation is somewhat more favourable for workers in in-plant services, since laws governing transfers of undertakings force employers to either retain the incumbent workforce or buy workers out.

The cost-cutting strategy underpinning concessionary agreements at the OEMs institutionalizes worker acceptance for these measures, while making it more difficult to organize a more "peripheral" workforce. IG Metall has taken on the task of organizing new establishments, international colleagues and employee groups. Nonetheless, these

\footnotetext{
${ }^{5}$ For example, the Saxon transport employers association contains not only operators of logistics firms and coach operators, but also hundreds of independent taxi drivers. There has not been a bargaining round since the mid-1990s, which has led to a wage freeze at six euros an hour.
} 
efforts have not prevented growing diversity in working conditions and the erosion of coordination between works councils, especially across the OEM-supplier divide.

\section{Discussion}

Vertical disintegration contributed to changes in industrial relations and working conditions in two sectors with different levels of union density, international exposure, labour intensity and history of public ownership. Workers at Deutsche Telekom's new subsidiaries, subcontractors, and competitors lack a sectoral agreement even as a reference point. Trade unionists in OEMs are hard-pressed to justify the cost of metalindustry wages for in-plant support services. The reassignment of work to an establishment with a different collective agreement (or no agreement) has led to a mix of firm, sectoral and occupational bargaining in each industry, where union strength is increasingly contingent on local power relations and actor strategies.

In the telecommunications and auto sectors, we have shown the effects of vertical disintegration on bargaining structures and wages and working conditions across several companies. Their strategies to segment work differ due to variation in union and works council bargaining power, as well as strategic choices by labour and management. However, all of the companies we examined have successfully cut costs and by-passed sectoral agreements for large groups of workers across their production chain through outsourcing work, spinning off subsidiaries, or contracting with temporary agencies. 
Lash and Urry (1987) argued over a decade ago that formerly organized or coordinated industrial relations institutions would become increasingly disorganised as social and economic organization grew more complex. The case of Germany long seemed to provide counter evidence of institutional resilience and path dependence. However, today it is widely recognized that the dual system as described by Streeck (1984), Thelen (1991) and Turner (1991) is turning into something very different, as a non-union sector expands (Hassel 1999), bargaining is decentralized to the firm and business-unit level (Katz \& Darbishire 2000), and firm-level pacts are "layered" on top of existing industrial relations arrangements (Rehder 2003; Streeck \& Thelen 2005). While these scholars have focused on the growing divide between a shrinking organized core and a disorganized periphery, we have shown that the two are closely linked. Vertical disintegration leads to the renegotiation of working conditions in both segments, because it breaks apart solidaristic bargaining across a formerly integrated production chain. These changes weaken coordinated bargaining and strong forms of industrial citizenship that traditionally distinguished European countries from the more liberal Anglo-Saxon countries.

Thelen has written the most coherent critiques of the disorganisation thesis, based on evidence that Germany's large employers continue to have an interest in maintaining centralized bargaining (Thelen and Kume 1999; Thelen and Van Wijnbergen 2003). She shows, first, that the 1995 Bavarian metalworkers strike exposed a conflict of interest between large firms, who wanted to retain the predictability of the system and smaller, firms who preferred militancy and cost-savings. In the end, the larger employers prevailed within the employers association and the strike was settled mostly on the 
union's terms. Second, despite neoliberal rhetoric from some quarters, most employers' associations remain committed to collective bargaining. Third, many managers in individual firms fear that dismantling the system would lead to more conflict with works councils and could lead to an expansion of union influence and works council rights. Lastly, shifts of jobs and capital to lower wage countries to the east continue to be modest.

We have shown that this picture is incomplete without attention to the segmentation strategies large firms are pursuing across their production chains. German employers have used outsourcing to move work out of sectoral agreements while maintaining a formal commitment to sectoral bargaining. Vertical disintegration does not require a union-busting motive, since it is - to managers and core firm worker representatives - merely a by-product of the search for flexibility and low costs. It does not require militant management, tough business associations, or even flight from collective bargaining (at least where lower-paying agreements exist). Large private firms like VW and Deutsche Telekom are able to remain publicly sympathetic to the need for codetermination and collective bargaining. As they shift work out of the core, they are not necessarily shifting capital and jobs out of Germany: most of the subcontractors discussed above employ a substantial domestic workforce.

These corporate strategies are more disruptive than other more commonly researched forms of restructuring, such as reforms to sectoral agreements, strikes, national industrial relations policy and firm-level pacts, because they move jobs to firms with weaker firm-level or no collective agreements or to firms belonging to a different sector. In both cases, coordinated bargaining across the production chain becomes next to 
impossible. German codetermination laws provide few formal tools for workers to shape this reorganisation, since they do not require consultation with worker representations over the terms of outsourcing or the establishment of joint ventures or subsidiaries. Organised labour's search for alternatives consists largely of compensating for the lack of influence provided by formal labour laws and bargaining structures.

Further research is needed to examine whether the findings from this study are generalisable to other sectors and countries. First, additional analysis of labour market data in Germany would provide a more complete picture of how wages, working conditions, and collective bargaining coverage are affected by vertical disintegration. It is likely that industries and firms differ in the ease with which managers have been able to outsource work, the extent of cost savings, and associated workers outcomes. While we have emphasized the similarities between vertical disintegration in autos and telecommunications, there are also clear differences in the resilience of sectoral bargaining institutions and union and works council strategies. More systematic analysis of these differences may help to identify the conditions under which unions may be more or less successful in influencing outsourcing decisions.

Second, further comparative research is needed to examine the role of national institutions in shaping outsourcing strategies and their effects. Differences in labour law, collective bargaining structures, and trade union strategies across "social Europe" are likely to influence the ease with which employers are able to segment work across firms, and the incentives to do so. For example, in Scandinavian countries the right to secondary boycotts has given unions more leverage to pressure employers to remain under sectoral agreements. A comparative study of MNCs in the Dutch and German 
telecommunications industry found that the same companies used temporary agencies in the Netherlands and subcontractors in Germany to improve staffing flexibility (DeGrip et al. 2005). These strategies had similar motivations but different outcomes for workers, due to strong negotiated protections for temporary agency workers in the Netherlands.

Vertical disintegration is becoming an increasingly important strategic issue for unions world-wide, but relatively little is known about the effects on collective bargaining. This paper has shown that German trade unions are having difficulty adjusting to more decentralised production networks and are often weakened by outsourcing strategies as it becomes more difficult to regulate wages and working conditions across the production chain. Germany's seemingly strong, flexible, and encompassing industrial relations institutions have as yet provided few mechanisms for bridging the segments of the labour market hardened by corporate restructuring. 


\section{Works Cited}

Arzbacher, S., Holtgrewe, U. and Kerst, C. (2002). 'Call Centres: Constructing Flexibility'. In Holtgrewe, U., Kerst, C. and Shire, K. (eds.), Re-Organising Service Work: Call Centres in Germany and Britain. Aldershot: Ashgate, pp. 1941.

Behrens, M. and Jacoby, W. (2004). 'The Rise of Experimentalism in German Collective Bargaining'. British Journal of Industrial Relations, 42 (1): 95-123.

Blau, J. 2003. IBM Invades Germany. Review of Reviewed Item. CIO Magazine, http://www.cio.com/archive/040103/tl_outsourcing.html.

Caprile, M. Outsourcing and industrial relations in motor manufacturing 2000 [cited February 2005. Available from http://www.eiro.eurofound.eu.int/2000/08/study/tn0008201s.html.

DeGrip, A., Doellgast, V., Holtgrewe, U., Shire, K., Sieben, I. and Jaarsveld, D. v. 2005. Negotiating Flexibility in Call Centers: The Netherlands and Germany Compared. Paper read at Presentation at the 57th Annual Industrial Relations Research Association Meeting, at Philadelphia.

Doellgast, V. (2006). Negotiating Flexibility: The Politics of Call Center Restructuring in the US and Germany, School of Industrial and Labor Relations, Cornell University, Ithaca, NY.

Doeringer, P. B. and Piore, M. J. (1971). Internal Labor Markets and Manpower Analysis. Lexington, MA: Heath Lexington.

Dore, R. (1973). British factory, Japanese factory: The Origins of National Diversity in Industrial Relations. Berkeley, CA: University of California Press.

Dribbusch, H. 2003. Packages of collective agreements signed for temporary agency workers. Review of Reviewed Item. European Industrial Relations Observatory Online (EIRO), http://www.eiro.eurofound.eu.int/print/2003/08/feature/de0308203f.html.

Frege, C. (2003). 'Transforming German Workplace Relations: Quo Vadis Cooperation?' Economic and Industrial Democracy, 24 (3): 317-347.

Hall, P. and Soskice, D., eds. (2001). Varities of Capitalism. New York: Oxford University Press.

Harrison, B. (1994). Lean and Mean: The Changing Landscape of Corporate Power in the Age of Flexibility. New York: Guilford Press. 
Hassel, A. (1999). 'The Erosion of the German System of Industrial Relations'. British Journal of Industrial Relations, 37 (3): 483-505.

Hassel, A. and Rehder, B. (2001). 'Institutional Change in the German Wage Bargaining System: The Role of Big Companies'. MPIfG Working Paper 01/9.

Hendrix, U., Abendroth, C. and Wachtler, G. (2003). Outsourcing und Beschäftigung. Munich: Rainer Hampp Verlag.

Höpner, M. (2003). Wer Beherrscht die Unternehmen? Shareholder Value, Managerherrschaft und Mitbestimmung in Deutschland. Frankfurt: Campus Verlag.

Jackson, G. (2005). 'Contested Boundaries: Ambiguity and Creativity in the Evolution of German Codetermination'. In Streeck, W. and Thelen, K. (eds.), Beyond Continuity: Institutional Change in Advanced Political Economies. Oxford: Oxford University Press, pp. 229-254.

Jacobides, M. G. (2005). 'Industry Change Through Vertical Disintegration: How and Why Markets Emerged in Mortgage Banking'. Academy of Management Journal, 48 (3): 465-498.

Katz, H. and Darbishire, O. (2000). Converging Divergences. Ithaca: ILR Press.

Kinkel, S. and Lay, G. 2003. Fertigungstiefe -- Ballast oder Kapital? Karlsruhe: Fraunhofer Institut fuer Systemtechnik und Innovationsforschung.

Kwon, H. and Kwon, H. (Forthcoming). 'The Growth of Nonstandard Employment, Changing Labor Market Structure and Industrial Relations'. In Lee, C. (ed.) Changing Industrial Relations of the Large Firm Sector in Korea. Seoul, Korea: Korea Labor Institute.

Lash, S. and Urry, J. (1987). The End of Organized Capitalism. Cambridge: Polity Press.

Marchington, M., Rubery, J. and Cooke, F.-L. (2005). 'Worker Representation and Voice Across Organisational Boundaries'. In Marchington, M., Grimshaw, D., Rubery, J. and Willmott, H. (eds.), Fragmenting Work: Blurring Boundaries and Disordering Hierarchies. Oxford: Oxford University Press, pp. 239-260.

Massa-Wirth, H. and Seifert, H. 2004. German Pacts for Employment and Competitiveness: Concessionary Bargaining as a Reaction to Globalization and European Integration? In Paper presented at the International Industrial Relations Association 7th Annual Congress. Lisbon, Portugal.

Paterson, W. and Green, S., eds. (2005). Governance in Contemporary Germany: The Semisovereign State Revisited. Cambridge: Cambridge University Press. 
Piore, M. J. and Sabel, C. F. (1984). The Second Industrial Divide: Possibilities for Prosperity. New York: Basic Books.

Rehder, B. (2003). Betriebliche Bündnisse für Arbeit in Deutschland: Mitbestimmung und Flächentarif im Wandel. Frankfurt: Campus Verlag.

Rossmann, W. 2001. Gewerkschaften im marktwirtschaftlichen Auflösungsprozeß? Perspektiven der industriellen Beziehungen. Cologne.

Sako, M. and Jackson, G. (2006). 'Strategy Meets Institutions: The Transformation of Labor Relations at Deutsche Telekom and NTT'. Industrial and Labor Relations Review, 59 (3): 347-366.

Schroeder, W. and Silvia, S. (2003). 'Gewerkschaften und Arbeitgeberverbaende'. In Schroeder, W. and Wessels, B. (eds.), Die Gewerkschaften in Politik und Gesellschaft der Bundesrepublik Deutschland. Wiesbaden: Westdeutscher Verlag, pp. 244-270.

Schroeder, W. and Wessels, B., eds. (2003). Die Gewerkschaften in Politik und Gesellschaft der Bundesrepublik Deutschland. Wiesbaden: Westdeutscher Verlag.

Springer, R. (1999). Rückkehr zum Taylorismus? Arbeitspolitik in der Automobilindustrie am Scheideweg. New York: Campus.

Streeck, W. (1984). Industrial Relations in West Germany: A Case Study of the Car Industry. London: Heinemann. (1992). Social Institutions and Economic Performance. London: Sage.

- 2001. The Transformation of Corporate Organization in Europe: an Overview. Cologne: Max Planck Institute for the Study of Societies.

Streeck, W. and Thelen, K. (2004). 'Introduction: Institutional Change in Advanced Political Economies'. In Streeck, W. and Thelen, K. (eds.), Beyond Continuity: Institutional Change in Advanced Political Economies. New York: Oxford University Press, pp. 1-39.

Thelen, K. (1991). Union of Parts: Labor Politics in Postwar Germany. Ithaca: Cornell University Press.

Thelen, K. and Kume, I. (1999). 'The Effects of Globalization on Labor Revisited: Lessons from Germany and Japan'. Politics and Society, 27 (4): 477-505.

Thelen, K. and Van Wijnbergen, C. (2003). 'The Paradox of Globalization: Labor Relations in Germany and Beyond'. Comparative Political Studies, 36 (8): 859880. 
TPI. 2005. Europe Outsourcing Capital of the World. Review of Reviewed Item., http://www.tpi.net/pdf/newswire\%20vnu\%20011405\%20europe\%20outsourcing $\% 20$ capital $\% 20$ of $\% 20$ the $\% 20$ world $\% 20$ quotes $\% 20$ duncan $\% 20$ aitchison.pdf.

Turner, L. (1991). Democracy at Work: Changing World Markets and the Future of Labor Unions. Ithaca: Cornell University Press.

Yamamura, K. and Streeck, W., eds. (2003). The End of Diversity? Prospects for German and Japanese Capitalism. Ithaca: Cornell University Press. 